\title{
Hypothalamic hamartoma with pubertas precox and gelastic seizure in a boy (Case Report)
}

\author{
Iman Hendarman*, Aditiawati, Msy Rita Dewi Arifin \\ From 7th APPES Biennial Scientific Meeting \\ Nusa Dua, Bali. 14-17 November 2012
}

Hypothalamic hamartoma is a rare neoplastic heteropia caused by organic developmental failure. The most common clinical findings in hypothalamic hamartoma are pubertas precox with or without gelastic seizure, and behavioural disturbance. The aim of this case report to inform a rare case of hypothalamic hamartoma with pubertas precox and gelastic seizure in a boy.

A 5 year and 7 month old boy, admitted to the hospital with a chief complain of premature pubic hair growth and frequent sudden laughing without apparent reason which seemed to be forced, uncontrolled, irregular without deteroratoin of consciousness. Physical examination found accelarate height growth with appropriate proportion. Tanner pubertal status was $\mathrm{A}_{1} \mathrm{P}_{2} \mathrm{G}_{2-3}$, and neurological status was normal. Laboratory finding: $\mathrm{FSH}$ : 0,5 $\mathrm{mlU} / \mathrm{ml}$, LH: 0,85 $\mathrm{mlU} / \mathrm{ml}$, testosterone: $239,20 \mathrm{ng} / \mathrm{dL}, 17 \alpha-$ hydroxyprogesterone: $107 \mathrm{ng} / \mathrm{dl}$. Cranial CT scan and MRI showed a space occupying lession in suprasellar region which was suspected as a tubercinerium hamartroma. Bone age result was appropriate for an 8 year and 6 month old boy. He was treated with leuprorelin $1 \times 3,75 \mathrm{mg}$ intramuscular every 4 week and valproic acid $2 \times 200 \mathrm{mg}$. After 3 years evaluation, patient's Tanner pubertal status was $A_{1} P_{2} G_{2-3}$ and the bone age was appropriate for an 13 years old boy. No gelastic seizure.

Leuproleline effectivity as a therapy for pubertas precox with hypothalamic hamartoma is still a controversion, so management through surgical approach may be considered, and valproic acid has a good effectivity for gelastic seizure in this case.

Published: 3 October 2013

Department of Child Health, Faculty of Medicine Sriwijaya University/Dr. Mohammad Hoesin Hospital, Palembang, Indonesia
doi:10.1186/1687-9856-2013-S1-P196

Cite this article as: Hendarman et al:: Hypothalamic hamartoma with pubertas precox and gelastic seizure in a boy (Case Report).

International Journal of Pediatric Endocrinology 2013 2013(Suppl 1):P196.
Submit your next manuscript to BioMed Central and take full advantage of:

- Convenient online submission

- Thorough peer review

- No space constraints or color figure charges

- Immediate publication on acceptance

- Inclusion in PubMed, CAS, Scopus and Google Scholar

- Research which is freely available for redistribution
() Biomed Central
() Biomed Cental

(c) 2013 Hendarman et al; licensee BioMed Central Ltd. This is an Open Access article distributed under the terms of the Creative Commons Attribution License (http://creativecommons.org/licenses/by/2.0), which permits unrestricted use, distribution, and reproduction in any medium, provided the original work is properly cited. 